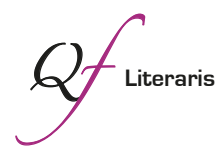

\title{
Ferrarese Chronicles in the Modern Era
}

\author{
Crónicas ferraresas en la época moderna
}

\author{
Diane Yvonne Francis Ghirardo
}

University of Southern California. ghirardo@usc.edu

Recibido: 20/03/2017. Aceptado: 14/11/2017

\begin{abstract}
In 1928, Giuseppe Pardi published the first of three fifteenth century chronicles of Ferrara. His edition of one of these chronicles, the Diario ferrarese dall'anno 1409 sino al 1502, replaced the eighteenth-century version published by Ludovico Muratori. Pardi showed a modern understanding of the challenges posed by transcribing antique documents, refusing to alter any of the material, and enriching the chronicles with full scholarly apparatus. Despite the availability and easy accessibility of material unimaginable until recently, late twentieth-century transcriptions fall woefully short of the standard set by Pardi. This paper explores the transcriptions of the chronicles, in particular the Pardi editions, illustrating how the early twentieth-century was a golden age unequaled before or since.
\end{abstract}

Keywords: Ferrara; chronicles; Renaissance; antique documents; textual edition.

Resumen: En 1928, Giuseppe Pardi publicó la primera de tres crónicas del siglo XV sobre Ferrara. Su edición de uno de estas tres crónicas, el Diario ferrarese dall'anno 1409 sino al 1502, sustituyó versión del siglo XVIII publicada por Ludovico Muratori. Pardi mostró una comprensión de los retos que presenta la transcripción de documentos antiguos, rehusando alterar este material y enriqueciendo las crónicas con un aparato crítico completo. A pesar de la disponibilidad y fácil acceso a materiales inimaginables hasta hace poco, las transcripciones de finales del siglo XX no llegan a los estándares establecidos por Pardi. Este artículo explora las transcripciones de las crónicas, en particular las de Pardi, ilustrando como los inicios del siglo XX fueron una época dorada sin igual antes o después.

Palabras clave: Ferrara; crónicas; Renacimiento; documentos antiguos; edición de textos.

》) Francis Ghirardo, Diane Yvonne. 2017. "Ferrarese Chronicles in the Modern Era". Quaderns de Filologia: Estudis Literaris 22: 131-153. doi: 10.7203/ qfed.22.11256 



\section{Introduction}

In the fifteenth and sixteenth centuries, Ferrara's status as one of the most celebrated of Italian cities was indisputable, as a center of literary, artistic and cultural production comparable to Florence, Rome, Naples and Venice. Much of that prominence faded following the devolution of the duchy to the papacy in 1598 (Guerzoni, 2001; Masetti Zannini: 2000). Papal legates systematically destroyed and plundered the architectural and artistic riches of the city, effectively executing a damnatio memoriae, leaving behind only a handful of treasures as haunting echoes of the city's Renaissance glory ${ }^{1}$. More difficult to banish, the city's literary icons, from Ludovico Ariosto's epic Orlando Furioso (Catalano, 1930-31) to Torquato Tasso's epic and love poetry, remained haunting reminders of a rich literary tradition (Broad, 1965; Gunsberg, 1998; Zatti, 2006) ${ }^{2}$. From the new Este duchy of Modena and Reggio, the Este court struggled to recover that prominence, including publishing documents to support their claims to Ferrara and celebrating the family's accomplishments over the course of nearly four centuries as the city's rulers ${ }^{3}$. Even after the Este abandoned the duchy of Ferrara, local historians sought to document and, where possible, to highlight some of that history. As court archivist and historian, Ludovico Muratori's ${ }^{4}$ contributions to this effort included celebrating the Este family's ancient and illustrious lineage (Muratori, 1717/1740), but also by incorporating one of the city's major fifteenth-century chronicles in his monumental Rerum Italicarum Scriptores (RIS), a collection of chronicles from Italian towns and cities spanning a thousand years, from the year 500 to

\footnotetext{
${ }^{1}$ In the north of Ferrara, the fifteenth-century villa of Belfiore, with its frescoes celebrating Eleonora d'Aragona and Leonello d'Este's extraordinary study, was destroyed, as was Alfonso I d'Este's fabulous island villa of Belvedere (Marchesi, 2015: 5-145). The stunning villa of Belriguardo to the south-east of the city fell slowly into ruins that even today testify to its former beauty (Marchesi, 2011: 26-104).

${ }^{2}$ Museums in Rome, Florence, Milan, France, Great Britain and the United States profited from the spoliation of the duchy's riches.

${ }^{3}$ A full bibliography can be found in Guerzoni (2001).

${ }^{4}$ Born in Vignola, Ludovico Muratori (1672-1750) studied law in Modena, later receiving holy orders. In 1700 duke Rinaldo d'Este summoned him to Modena to serve as the librarian. His distinguished career included the publication of the Rerum Italicarum Scriptores as well as numerous publications on Catholicism, even while serving as a priest at a church in Modena (Imbruglia, 2012).
} 
1500: Diario ferrarese di autori incerti (1409-1502) (Muratori, 1738: 155-406), henceforth Diario I. Muratori originally planned four tomes, but as word spread, scholars from around the peninsula submitted an increasing number of chronicles, bringing the total to twenty-five ${ }^{5}$.

After the flurry of Muratori's eighteenth-century publications, interest in transcribing Ferrara's chronicles revived only in the twentieth century. Edited by Giuseppe Pardi (1870-?), a new edition of the Rerum Italicarum Scriptores with Diario I appeared in 1933, henceforth Diario II (Pardi, 1928-1933), along with a second chronicle, that of Bernardino Zambotti (Zambotti $)^{6}$. Pardi also edited a third chronicle, Diario di Ugo Caleffini (1471-1494), published in two volumes, henceforth Caleffini I. Giovanni Maria Zerbinati's diary appeared in 1989 (Zerbinati), followed by a new edition of Caleffini (Caleffini II) and the diary of Girolamo Ferrarini (Ferrarini $)^{7}$, both in 2006. Together the chronicles provide a rich portrait of life in early and high Renaissance Ferrara, including details of the duchy's wars, diplomatic events, internal politics, marriages, scandals, alliances and betrayals, in short, the duchy's social, cultural and religious life as understood at the time. The high point of these publications nonetheless came not in the eighteenth century with RIS, nor, with one exception (Ferrarini), with the late twentieth and early-twenty-first century chronicles, but with those of the new, Carducci inspired editions, and in particular, for the Ferrarese chronicles, by editor Giuseppe Pardi in the 1920s and 1930s.

\section{The Chroniclers}

In their introductions to the Diario, Muratori and Pardi speculated on the text's author ${ }^{8}$. Muratori presented a one-paragraph preface in Latin to situate Diario I within the larger RIS project, followed by a brief

\footnotetext{
${ }^{5}$ A new edition of the RIS began in 1900 under at the prodding of Giosuè Carducci and continued by others, and a third, sponsored by the Istituto Storico Italiano per il Medio Evo (ISIME) began in 1999.

${ }^{6}$ The original manuscript is conserved in the Biblioteca Comunale Ariostea (BCA) di Ferrara, Zambotti, Silva Cronicarum Bernardini Zambotti Juris Civilis Doctoris Ferrariensis sed incepta dum esset scolaris anno MCCCCLXXV, ms. cl. I, 470.

${ }^{7}$ The original is in the Biblioteca Universitaria Estense, Modena, MS IT 178, alpha F.5.18.

${ }^{8}$ The original manuscript of Diario $I$ is held by the Estense Library in Modena BCA, ms. cl. I, 470.
} 
discussion of the unknown author, noting that the writing suggested an individual of humble origin, neither cultivated nor illiterate. Hence the text was a chronicis popularibus that, while useful, suffered from limitations deriving from the author's social status (Diario I, "Praefatio"). Pardi's sixteen-page preface to Diario II discussed the same points in greater detail. With entries spanning nearly a century, and despite the consistency of the handwriting throughout, Pardi argued that internal evidence suggested that the early part, from 1409 through the late 1460 s, comprised a compilation of material from earlier chronicles assembled by the unknown author ${ }^{9}$. The first part indeed reads like an edited summary, while the events after 1467 are recounted at a level of detail that persuasively position the author as a direct witness: the years from 1409 to 1467 occupy only 46 pages, while the years from 1468 to 1502 expanded to 243 pages $^{10}$. Other internal evidence indicates that, not being close to the court, the author was therefore unable to record anything other than general information about the ruling family and courtiers. Although sharing Muratori's belief that the author was not particularly cultivated, Pardi specified that he based this opinion upon factors such as the author's relatively uncommon language, a combination of Venetian and Ferrarese dialects, but also on material that did not make it into the diary, such as events related to the University of Ferrara (Studio di Ferrara), one of the city's glories in the fifteenth century and which from time to time was the scene of tumult, conflict and disorder. That the Studio barely surfaced suggests a non-academic but literate author, perhaps a notary (Diario II, xviii) ${ }^{11}$.

By contrast, notary Bernardino Zambotti's highly ranked family from the upper levels of Ferrarese society positioned him close to the court, through the sinecures he held and through highly-placed relatives (Folin, 2000: 4; Chiappini, 1954). In his successful career as a ducal

\footnotetext{
${ }^{9}$ Copying and summarizing earlier chronicles was a common practice among Ferrarese diarists. Giovanni Maria Zerbinati copied parts of the chronicle originally drafted by Paolo Zerbinati, who lived through the events described; the original was longer, as Giovanni noted (Zerbinati, 7).

${ }^{10}$ As Pardi noted in Diario II (xvi) already in the year 1419 the author mentioned is the duca Borso - yet Borso did not become duke until 1452.

${ }^{11}$ Pardi proposed the notary Francesco da Fiesso, in part because the diary includes many references to events in Fiesso, suggesting the author's strong ties to the town across the Po River in the area known as the Alto Polesine.
} 
official, Zambotti even served as a judge in Ferrara and elsewhere. Late in life, count Uguccione Contrari, scion of the wealthiest family in Ferrara, selected him as secretary and counselor. In the summer of 1503, Contrari sent his wife Diana d'Este with Zambotti to the Contrari castle in Vignola, having given the notary full jurisdictional powers to govern the Contrari holdings. Zambotti's chronicle ends in 1504, probably because once distant from Ferrara, he lacked the kind of information that enriched his chronicle in previous years. His close connections to the ducal family and its courtiers gave him access to details not available to the anonymous author of Diario I. For example, when Cardinal Ippolito I d'Este, then cardinal of Hungary, returned to Ferrara in the summer of 1494, Zambotti spelled out the details with meticulous precision, from Ippolito's arrival from Padua to the tearful encounter with his recently widowed father, Ercole I d'Este (Zambotti, 234). With his legal education and his proximity to the highest reaches of the court, Zambotti enjoyed almost immediate access to news from elsewhere which in Italy was typically communicated first to the duke. As a result, of all of the chroniclers from the late fifteenth and early sixteenth century, he was the most attentive to local and Italian politics. To be able to cover in such explicit detail the arrival of the French king Charles VII in Rome in January 1495 scholars speculate that he must have seen dispatches from the ducal orator in Rome, including the specifics of the pact drawn up between the king and pope Alexander VI (Zambotti, 245-6).

The last chronicle to be transcribed appeared in 2006, that of Girolamo Maria Ferrarini, covering the years between 1476-1489, a brief thirteen years penned by a quite loquacious author.

Girolamo Maria Ferrarini came from a social background of wealth and high status similar to that of Zambotti; indeed, they studied jurisprudence together at the Studio of Ferrara, were close friends, and began writing their chronicles while both were students (Folin, 2000: 4). Nonetheless, Ferrarini's interests differed dramatically from those of Zambotti. Fortunately for the historian, the details of daily life in his family and that of others drew Ferrarini's attention, as did cultural events, spectacles, weddings, funerals and banquets.

As Primo Griguolo described in his introduction, the manuscript is in Ferrarini's own hand, and includes interlinear adjustments by the author. Although organized chronologically, such additions and marginalia often refer the reader to subsequent or earlier pages, indicat- 
ing that Ferrarini returned repeatedly to and edited his own text over time. A notary based in Ferrara but originally from Lendinara, Ferrarini was a close friend of Zambotti from their days at university; indeed, they chose to begin their diaries at approximately the same time, and Ferrarini repeatedly referred to events they attended together or meals that they shared. More than the other diarists, Ferrarini entered much personal information, including marriages, births and deaths in his family -even, unusually, providing the names of women- but also other personal matters, such as his own fears of the plague and his attempts to avoid contagion. His account of a brief fling with Isabetta, the granddaughter of a barber in Ferrara, may surprise today's reader, for Ferrarini even breezily noted that the young woman became pregnant and gave birth to a daughter, who died shortly afterwards, in March 1483 (Ferrarini 176). As he recounted events he believed to be significant, Ferrarini also often added the remark that he was a personal witness of what he described, ensuring that later readers could credit the truthfulness of his observations. By contrast with Zambotti, Ferrarini tended to emphasize local, even intimate materials, recording his travels and those of family members. Deaths from the plague, and especially the prices of goods in Ferrara's markets, occupied the diarist more than did political events in the peninsula, although his detailed accounts of troop movements, victories and defeats during the 1482-84 Salt War nicely supplement Zambotti and Caleffini.

The fourth diarist, Ugo Caleffini, was also a notary from a relatively prominent family recently transferred to Ferrara from Rovigo. His father, brothers and brothers-in-law were all either notaries, or held public offices (Petrucci, 1973: 647-50) but their status was inferior to that of the Zambotti family. Caleffini also produced two other chronicles: one on the history of Ferrara from 38 AD to 1471 AD, as yet unpublished, and another on the Este dynasty ${ }^{12}$. The chronicle under consideration here spans two-thirds of the rule of Ercole I d'Este, from 1471 to 1494. Most of what is known of Caleffini comes directly from his diary,

\footnotetext{
${ }^{12}$ Cronaca di Ferrara dalle origini al 1471, Biblioteca Nazionale di Firenze, Magliab. XXV.539, and Cronica della Casa d'Este, ASMo, Casa e Stato, Genealogie, B. 60, published in A. Cappelli, Notizie di Ugo Caleffini notaro Ferrarese de secolo XV con la sua cronaca in rima di Casa d'Este, in "Atti e Memorie della Deputazione Modenese di Storia Patria”, s. I, II, 1867, 267-312.
} 
where he included many mentions of weddings, births, deaths and other important events having to do with his family. His status meant that Caleffini did not have access to the kinds of information from throughout Italy enjoyed by Zambotti and Ferrarini, but at the same time, he provided long and detailed accounts of events that unfolded in Ferrara, much as Paolo Zerbinati did. The last of the chroniclers, Paolo Zerbinati, headed the ducal mint and often acted as an attorney for Alfonso I d'Este, and like Caleffini, occupied lower levels of the city's bureaucracy ${ }^{13}$. Much of what we know of the authors comes directly from their chronicles. Caleffini recounted marriages and other family events, but he also voiced his deep resentment over the loss of benefices in lands near Fiesso that had been invested in him and his brothers by papal commissioners in 1475. Barely two years later, the duke forced the brothers to renounce those benefices in favor of their cousins, the Fiaschi brothers, one of whom was a well-connected ducal chamberlain, a decision that clearly embittered the diarist toward the duke (Caleffini I, 237-9). Unusually among Ferrara's chroniclers, Caleffini also cast a critical eye on the ducal court, frequently criticizing the duke's sale of offices as a mean of collecting money for his lavish expenditures on buildings and festive events.

Paolo Zerbinati, the original author of Zerbinati, wrote of the events from 1500-1527 as a direct witness. The evidence shows that, as copied by a descendant, Giovanni Maria Zerbinati, the chronicle omitted many items on the grounds, as Giovanni wrote, that he had included items that "either were not present in or different from other chronicles he had seen" (Zerbinati, 37). A definitive assessment of Paolo's intentions is difficult to undertake because of the unknown omissions. As copied, for example, the chronicle seems to avoid politics, and appears relatively neutral toward the Este family. Whether this depended upon decisions made by Giovanni Maria or Paolo we cannot know. Indeed, there is relatively little information about the ducal family overall in the chronicle, while the coverage of the second Salt War (1509-1513) was extensive, with 54 of 128 pages dedicated to it, but we do not know which of the two men elected this emphasis (Zerbinati, 78-131).

\footnotetext{
${ }^{13}$ G. M. Zerbinati, Memorie, in "Monumenti della Deputazione provinciale Ferrarese di Storia Patria", XIII, 1988, 7-32.
} 


\section{The Published Chronicles}

Muratori's transcription of Diario I consists of 123 double-columned pages, considerably fewer than that of Pardi. Other than the brief preface and the text itself, Muratori included no additional materials. By contrast, the most notable feature of Pardi's Diario II and Zambotti are the extensive annotations appended by the editor, and he also provided full, remarkably complete indices of names and subjects, a chronological index of events for rapid consultation, and references to the original manuscript's page numbers. At the top of each page is the year referenced in the text, a significant improvement over Muratori's edition, where one must scan page after page to identify the year in question. The index of names lists the context in which the individual appeared, such as Fabrizio Caraffo, who "leaves for Naples with an honorable escort"14 and the relevant page number. The chronology briefly details significant events by year, month and day, followed by page and line references: "1438 March 4 - Arrival in Ferrara of the Emperor of Constantinople for the Council, p. 22, 10-11"15. These scholarly standards are common to the entire Carducci edition of the pre-1500 chronicles.

Pardi's annotations are perhaps the most valuable feature of the two diaries, and his accomplishment here was significant. He identified each of the individuals mentioned in the text, offering biographical details, where available. In other cases, he explained words or expressions in dialect. The term 'tratta,' for example, means 'to pull up the [fishing] nets" 16 . When he could, Pardi also drew material from other sources, such as when the anonymous diarist noted, on May 2, 1502, that

the Adige grew so much around Verona, Padua and the Polesine of Rovigo that it flooded and engulfed all of those towns; and the rupture was so great that the waters extended eleven miles and even reached Marina; and the damages were huge and impossible to quantify.

To support this point, Pardi added a reference from Venetian diarist Marino Sanuto $(1880,265)$ : "At this time the Adege flooded the Poles-

\footnotetext{
14 “...riparte per Napoli accompagnato onorvolmente”, 82 (Diario II, 299).

15 “1438 marzo 4 - Arrivo a Ferr. dell'Imp. di Costantinopoli per il Concilio 22, 10-11

(Diario II, 337).

${ }^{16}$ Note 4: "Tratta = tirar su le reti".
} 
ine"17. Elsewhere Pardi compared the accounts of the anonymous diarist with those of Zambotti. When Caterina Sforza of Forlì challenged her husband's assassins in 1488, as her husband's assassins threatened to kill her six children if she did not abandon the Rocca of Forlì, Diario I quoted Caterina Sforza as saying, "Viva the duke of Milan! I don't want to give you the Rocca; if you kill my children you will be punished". In a note, Pardi added Zambotti's account, "that she would never consign the Rocca, she would instead destroy the whole territory, if they [killed] her children, reminding them that she had another in her womb"18.

In some cases, Pardi explained his puzzlement about a statement in the original, or he corrected what appeared to be obvious errors. For example, Pardi questioned the author's report of Duke Federico Montefeltro's death:

And on the same day [25 April 1502] the news arrived in Ferrara that duke Frederick of Urbino died in Urbino and that he left as his heir the Roman [Catholic] Church, because he had no children.

Pardi's annotation signaled the notice's inaccuracy:

These news are incomprehensible. The duke then was Guidobaldo [...] But Guidobaldo had an heir, his nephew Francesco Maria della Rovere, the oldest son of his sister Giovanna, who was married to Giovanni della Rovere, prefect of Rome and lord of Sinigallia, who died in November $1501^{19}$.

In another instance, after the chronicler claimed that Plautus's play, Menaechmi, was to be staged a second time to honor Beatrice d'Aragona, Queen of Hungary, Pardi noted that a contemporary letter of Isabella d'Este in 1501 mentioned four Roman comedies staged between the

\footnotetext{
17 “...cresète tanto lo Atice [Adige] in Veronese, Paduana et Polesene di Roigo [Rovigo] che rupe et afundò tuti quilli paesi de là; et fu la rota tanto grande che l'acqua per undici miglia era larga et andava per insino a marina; et fu grandissimo et inestimabile danno" (Diario II, 287)

18 "Viva il duca de Milano; io non vi voglio dare la Rocha; se farete morire miei figlioli, vui seriti niponeta" (Diario I, 124).

19 “...Et in quello giorno se have nova in Ferrara che il duca Federico de Urbino era morto in Urbino et havea lasato suo herede la Giesia romana, perché non havea fioli alcuni" (Diario II, 287).
} 
end of January and early February in Ferrara, but the Menaechmi was not one of them (Diario II, 265). In short, Pardi engaged in a dialog with the manuscript based upon his own erudition, correcting, probing and elaborating as he deemed appropriate. He also played Diario II and Zambotti against one another to compare or clarify points raised by one or the other. As a typical example, consider the anonymous author's statement that the duke of Ferrara asserted dominion over Carpi against the claims of the Pio family in 1497; Pardi appended Zambotti's point that the duke had a commissioner and a podestà (mayor) on site to sort matters out ${ }^{20}$.

Another measure of the difference in tenor of the Muratori and Pardi editions is to compare the omissions in the former. Muratori excluded some passages from the diaries because they were incorrect. For example, he edited out a comment from 13 August 1496, about French troops bringing sustenance to the troops in Naples ${ }^{21}$. Pardi appended a note explaining the omission, but added that in those very days, a depleted force of French troops was besieging the city of Atella, near Pozzuoli, leading French general Montpensier to negotiate a truce and agree to abandon the Kingdom of Naples; Pardi also suggested that the chronicler might have been confused by news of six French ships sent to Gaeta by King Charles VIII ${ }^{22}$. Pardi believed that Muratori omitted the passage because it was in error, even though Muratori did not explain what he omitted or why, here or elsewhere. The anonymous diarist reported that Venetians were bringing 60,000 Turks to Italy, but King Matthias of Hungary intervened, and all drowned. Pure fantasy, Pardi observed, but he nonetheless included it ${ }^{23}$. As Pardi observed in his preface, just as the anonymous diarist probably selected the items from the earlier chronicles covering the years 1409 to 1467 that he believed "were worthy of note" (Diario II, xvi), so too did Muratori omit large parts of the two diaries that he deemed inappropriate. "The illus-

\footnotetext{
20 "se ha per certo, come il facto di Carpi era coneso in questo modo, videlicet, ch'el duca de Ferrara de cetero havesse avere il dominio de Carpi e Carpesani...", 13 August 1497 (Diario II, 203). Pardi noted how Zambotti (316) "precisa così poteri attribuiti al duca di Ferrara a Carpi: 'ge tenga uno comisario fazi razone a tuti e così uno podestà'". 21 "Una parte de l'armata del Re de Franza cum combatenti è andata in lo reame de Napoli con victuaglia a Franzosi”, 13 August 1496 (Diario I, 187).

${ }^{22}$ The missing passages from Muratori's Diario I, would have been on page 333; Diario II, 187.

23 “Voci fantastiche soppresse nell'ed. del Muratori.", 1 July 1484 (Diario II, 115).
} 
trious Historian," Pardi noted, "likewise omitted from his transcription everything that he thought unimportant or that which was incompatible with the dignity of History" 24 .

Pardi normally indicated in a note those passages omitted by $\mathrm{Mu}-$ ratori, who diligently omitted salacious tales of any type, scandals, prostitution, events concerning individuals not of noble extraction, and anything that detracted from the honor and distinction of the Este. A good example is the case of a priest that exposed himself nude in a window to protest the fact that duke Ercole claimed a rich benefice to which he believed himself entitled. Muratori omitted this entire passage because, in Pardi's view, such a story may have offended his Catholic sensibilities $^{25}$. At this point in the Pardi transcription of Diario II, such scandalous stories began to appear with increasing frequency, one of the factors that led Pardi to speculate that perhaps a different author had taken over. The earlier writer(s) avoided discussions of internal social issues, particularly the salacious ones, instead focusing especially on political matters both within and without the duchy (Diario II, 131). From this point forward, beginning in the late 1460s, the emphasis shifted; indeed, the author only briefly mentioned the arrival of Charles VIII, King of France, in Italy in 1495, an ominous event with long term consequences for the Italian peninsula. Instead, he discussed fights between Ferrarese citizens, the prices of food, robberies, women's fashions and how three millers died when their boat overturned in the flood waters of the Po (Diario II, 135).

More surprising is Muratori's sharp abbreviation of the lengthy account of the life and funeral of Ludovico Casella, prime minister and secretary of state of duke Borso d'Este ${ }^{26}$. Widely esteemed as an honorable, deeply cultured and judicious man, unusual in his refusal to succumb to the temptations of his enormous power or to ill-gotten gains deriving from corruption, Casella earned the respect and trust of three successive Este rulers: Nicolò III, Leonello and Borso d'Este, not to mention that of the entire populace, according to the diarist. For his

\footnotetext{
24 “'L'illustre Storico, per altro, nel trascriverlo omise tutto ciò che gli parve poco importante o non confacentesi alla dignità della Storia" (Diario II, xviii).

25 "Forse ai suoi sentimenti di cattolico ripugnava l'aneddoto del prete di Modena", 2 June 1493 (Diario II, 131).

${ }^{26}$ Casella died 16 April 1469 (Diario II, 58-60); cfr. Ghirardo, 2014. In a later edition, the editors added an abbreviated version of the lengthy account.
} 
funeral Borso ordered all shops closed, personally donned sackcloth, repaired to Casella's house and tearfully accompanied the body to S. Domenico for the funeral-surprising everyone, as Borso notoriously avoided funerals, participating, if at all, only where obliged by family ties. Even more surprising, Pardi did not mention that Muratori had severely truncated Casella's story. As the diarist noted, Casella was not of noble extraction, so Muratori may have thought the life of someone not a "gentleman" not worth the praise and lavish space dedicated to him, and Pardi may have shared that view (Ghirardo, 2014: 119, 127).

After the tour de force of Diario II and Zambotti, Pardi's publication of Ugo Caleffini's chronicle was something of a disappointment, certainly not up to the high standards of his earlier work. Two copies of the manuscript exist, the original in the Vatican Apostolic Library, with a late sixteenth-century copy held by the British Library ${ }^{27}$. Essentially, Pardi's two-volume edition consisted of summaries of passages extracted from Caleffini I augmented by annotations and comments covering the same events in Diario II and Zambotti. These additions -all previously published in the earlier two diaries- render consultation of Caleffini I far more complex, for while this strategy facilitates direct comparisons of the three accounts, it eliminates most of the richness and even the details of Caleffini's account. Why he chose to publish such a limited version of the chronicle is unclear, particularly in light of the earlier, superior editions. Quite possibly the difficulties associated with having to go to Rome to consult the manuscript led him to elect to focus on comparisons, almost as a test of their veracity. A second, more compelling reason may be length: without introduction or indices, the 2006 edition comes in at a hefty 952 pages, while even with extensive notes, Zambotti and Diario II each number only half as many pages ${ }^{28}$.

In any case, these two volumes remained the only editions of Caleffini's important chronicle until the Deputazione Provinciale Ferra-

\footnotetext{
${ }^{27}$ Ugo Caleffini, "Croniche” Biblioteca Apostolica Vaticana, Chigi, I 4; Giulio Mosti and Girolamo Merenda transcribed the chronicle in the decades after 1580, a manuscript that was originally in the Costabili library but which is now in the British Library, London, with the title Annali di Ferrara, MS 22324. Folin, 459-92. This copy continues to the year 1534, as appended by don Girolamo Merenda at the beginning of the seventeenth century.

${ }^{28}$ Without the indices and additional material, Zambotti numbers 404 pages, while Diario II numbers 289 pages.
} 
rese di Storia Patria (DPFSP) sponsored Teresa Bacchi and Maria Giovanna Galli's new transcription of the complete text in 2006. By contrast with that of Pardi, this new edition includes the entire chronicle, with headings for the various topics and references to the corresponding pages in the original. Unlike Muratori's eighteenth-century RIS chronicles, Caleffini II places the year at the top of every other page, facilitating rapid consultation, just as Pardi had done. The authors also set out the standards used in the transcription, an essential component missing from both Muratori and Pardi. To well-deserved compliments for the felicitous completeness of this edition must be added serious criticism of the lacunae: other than indices of names and places, unfortunately also riddled with errors, this edition lacks annotations other than to indicate cancelled or missing words. The dutiful researcher must turn to Pardi's two diaries for detailed explanations and identifications of the individuals named in the chronicle. Unfortunately, the 1989 publication of Giovanni Maria Zerbinati's early sixteenth-century diary (15001527) suffers from some of the same defects.

Editor Muzzarelli's twenty-five page introduction to Zerbinati consists of a synthetic but illuminating discussion of the chronicle's historical context, details of specific events, along with observations about this chronicle in comparison with others. Although Giovanni Maria Zerbinati assembled the manuscript in the early seventeenth century, Paolo Zerbinati penned the original a century earlier. Like the anonymous author of the Diario ferrarese, Giovanni stated that he had omitted many parts of his ancestor's account. He chose to record primarily things that were less clear, shorter or simply did not appear in other chronicles (Zerbinati, 37). The original, still in the hands of Ferrarese historian Antenore Scalabrini at the beginning of the nineteenth century, has disappeared. Like the anonymous Diario $I$, in the truncated version handed down to us from Giovanni, Zerbinati focused less on politics in the Italian peninsula and Europe than on matters closer to everyday life, such as food prices, the seasons, draughts, floods, the condition of the Po, the second Salt War, and other curiosities of purely local interest. Muzzarelli's introduction recapitulated the topics addressed in the manuscript and added a helpful bibliography. She also advanced insightful observations about what Zerbinati chose to include and what to omit and, especially, what apparently escaped him. For example, she noted that while Zerbinati commented eloquently on the 
poverty of many Ferrarese, the high price of bread and the extravagance of the court, he indicated no political opposition to this state of affairs, or indeed, any reflections on possible connections between the two ( $\mathrm{Ze}$ rbinati, 19). Zerbinati also recounted in detail the events of what is known as the second Salt War, while Muzzarelli explained the larger issues associated with the war that the diarist could not have known (Zerbinati, 27-29).

Despite the helpful bibliography and the fine introduction, the only annotations to Muzzarelli's transcription concern missing words and marginal notes. Through 1504, comparisons with either the Diario II or Zambotti are possible, both for content and for identifying people, but for the rest of the text, the reader is at sea when seeking to identify individuals and other specifics about events. A reader not already familiar with Aldovrandino Sacrati, Borso Pendaglia, Ludovico Fiasco and others would be unable to assess their importance in early sixteenth-century Ferrara.

Primo Griguolo, a retired high school teacher, transcribed and edited the Ferrarini. Like all but the Muratori edition, Griguolo's transcription includes a full index. Of the seven chronicles considered here, only the most recent define the standards employed for the transcriptionsCaleffini II, Zerbinati and Ferrarini. Several features in Griguolo's edition set it apart from the others. Unusually, he included illustrations. Notable among these are Pellegrino Prisciano's sketch of the Herculean Addition of 1494, a papal bull from pope Alexander VI confirming Ferrarini as judge in Cesena, an eighteenth-century image of Lendinara with a map showing its location, several images from the Sala dei Mesi in Palazzo Schifanoia, and a miniature from Aristotle's Physics showing a teacher and his students. Most significantly, Griguolo added a fold out of Ferrarini's own color map with appropriate annotations for the battles along the Po in the crucial month of June, 1482. The introduction describes the manuscript, followed by a well-documented biography of Ferrarini, his family of origin and important events in his life. To this, Griguolo appended transcriptions of several documents, a family tree and letters, including a condolence letter from Bernardino Zambotti on the death of Ferrarini's maternal uncle. Like Pardi, Griguolo annotated the text extensively, primarily to identify individuals named by Ferrarini, but he supplemented this with bibliographic references as well as archival sources related to them-this last feature being particularly 
unusual and valuable. Ferrara's early modern notarial documents have not been inventoried, so the inclusion of such references for late fifteenth-century Ferrarese citizens is quite remarkable, and surely results from patient, time-consuming archival research over many years. To consult the manuscript, Griguolo had to travel from Rovigo to Modena, changing trains in Bologna both ways.

The highest standards of scholarship belong to the work of Pardi and Griguolo, both of whom enriched their transcriptions in remarkable, even if different, ways. Griguolo's archival references, illustrations, and documentary appendices position Ferrarini in his time in ways unmatched for the other diarists, while Pardi's rich and learned engagement and dialogue with Zambotti and the anonymous author of Diario II make for an exceptionally rewarding reading. Both clearly sought to inform scholars with as much collateral material as available, something that cannot be said of the other transcriptions. But Pardi, and particularly Muratori, had other objectives in mind for their scholarly projects.

Muratori's extraordinary labor of assembling chronicles from throughout Italy testified to far more than dispassionate scholarship. His deep patriotism and desire to see Italy recover its former greatness suffused his writings, especially beginning with his treatise in support of the Este dynasty's claims to the duchy of Ferrara against those of the church in $1725^{29}$. Early on he dreamed of establishing a league of the most accomplished scholars in the arts and the sciences to circulate information about their fields, but especially to grow them for the benefit "of the Catholic religion, the glory of Italy, and private and public profit" ${ }^{\prime 3}$. Muratori's training in canon law, his theological writings, and his experience as a parish priest did not include training as a historian, but when a bitter battle broke out in 1708 among the Church, the Este and Holy Roman Emperor Joseph I, Muratori stepped up to the challenge to document the claims of the Empire and the Este against the Church, particularly in his 1712 history, Piena esposizione dei diritti imperiali ed estensi in proposito delle controversie di Comacchio. In-

\footnotetext{
${ }^{29}$ The Centro di Studi Muratoriani in Modena holds annual conferences and publishes the proceedings with extensive bibliographies, most of which are available online: www.centrostudimuratoriani.it

${ }^{30}$ Ludovico Muratori, I Primi Disegni, in Opere, Giorgio Falco e Fiorenzo Forti, eds., 2 voll., Milano - Napoli, Ricciardi, 1964, 182.
} 
terrogating every conceivable ecclesiastical and imperial document in the course of covering a thousand years of history, Muratori trained himself to become a historian. From this base, Muratori (1717/1740) in short order undertook the Antichità estensi project, documenting the ancient and noble origins of the Este. At the same time, he initiated the RIS collection, initially planning four volumes of ancient chronicles, but ultimately publishing twenty-five tomes, with a total of twenty-eight volumes; the nine volume Annali d'Italia followed in short order. RIS's novelty, beyond the publication of long-forgotten chronicles, lay in Muratori's implicit revision of the longstanding conception of the 'barbarian' middle ages, and his presentation of sacred and secular history as inextricably intertwined. Equally importantly, this history (prior to the invasions and wars from the late fifteenth century forward) celebrated an Italy not yet under the heel of foreign powers, a country of rich literary and artistic treasures to be celebrated and freed from foreign control; he dreamed of an Italy restored to its proper status. For this reason, the terminal date of his collection was 1500. Muratori's ambitions differed little from those of Pardi two hundred years later.

Why Pardi undertook projects as massive as the transcription and annotation of three chronicles is no secret: he spelled out his reasons in the first pages of the two editions. Like Muratori, he found Diario II to be a vehicle for celebrating the many accomplishments of the Este, whether in architecture, art, theater, relations with other states, or in conspicuous and profitable marriages for family members. Also like Muratori, he drew parallels between the history and fate of Ferrara and those of the Italian peninsula as a whole. Beyond purely antiquarian interests, traces of early twentieth-century concerns emerge, for example, when Pardi claimed that the fifteenth-century city enjoyed steady and ample supplies of foodstuffs, sufficient to render thievery unnecessary (despite contrary evidence presented by all three diarists). Instead, Pardi blamed foreigners attracted by the city's prosperity for the street fights, robberies and other forms of criminal behavior frequently recorded in the diaries (Diario II, xii-xiii). In his preface to Zambotti, Pardi explicitly identified the end of the fifteenth century as the era when Italy began a three-hundred year slide into foreign domination only ended in the late nineteenth century. With its elevated culture, rich and productive agriculture, diverse commercial and refined industrial base, spectacular architectural and artistic treasures, and "a civilization far 
superior to any other part of Europe," (Zambotti, iii-iv) Pardi asserted that Italy attracted envy and, ultimately, a thirst for conquest by foreign powers. The diaries he transcribed, then, opened questions about why Italy's brilliant leaders failed to spare the peninsula's fatal descent into submission to foreign states. Indeed, the disaster was principally a military one, in Pardi's view, in which leaders proved incapable of grasping what it would take to halt the advance of French, Germans and Spanish troops (Zambotti, v). For Pardi, the reliance on mercenaries and general lack of preparation made even prosperous and wealthy cities such as Naples, Genova and Milan vulnerable to foreign armies.

To this must be added the era's other hallmark, endemic treachery. Emblematic is the case of Ferrara, where in 1509, as a member of the League of Cambrai along with Pope Julius II, Emperor Maximilian I, king Louis XII of France, king Ferdinand II of Aragon, and Francesco II Gonzaga of Mantua, Ferrara took up arms against Venice. A year later, Julius II changed his mind and joined with Venice to conquer Ferrara. In 1511, he managed to bring Ferdinand II into an expansion of the war now primarily against the French (Gullino, 2011). It is difficult not to see Pardi's observations in the 1930s as veiled support for greater military preparedness and self-reliance in Fascist Italy, and for greater attention to uneasy, questionable alliances.

Whatever the individual ambitions of the scholars who transcribed these chronicles in the twentieth century, taken together they brought forward a wealth of material about the social, religious, political and cultural life of Renaissance Ferrara. Zambotti's accounts proved particularly useful for understanding the enormous and ongoing architectural and urban transformation of Ferrara under duke Ercole I, from 1471-1505 in the studies of scholars such as Thomas Tuohy (1996), and, supplemented by Ferrarini and the anonymous diarist, Zambotti also recorded the first Salt War with compelling rigor. Zerbinati's account did the same for the second Salt War. Zerbinati, Zambotti and the anonymous diarist all detailed the arrival of Lucrezia Borgia in Ferrara as the bride of Alfonso I d'Este in February, $1502^{31}$, a welcome addition to the growing body of material on this fascinating woman. Along with

\footnotetext{
${ }^{31}$ Virtually all twentieth-century scholars to write about Lucrezia Borgia relied upon Zambotti's particularly complete account of the festivities surrounding the wedding; two of the most complete are Maria Bellonci (1939) and Sarah Bradford (2004).
} 
archival material, the diaries enabled scholars to document the history of Este villas such as Belriguardo and Belfiore, as well as how spaces in Este palaces and villas were used-and this despite the great unevenness in the modern publications (Manni, 2006; Sambin De Norcen, 2013; Shephard, 2014).

To the scholarly contributions of the chronicles must be added two quite different, late twentieth and early twenty-first century compilations by Adriano Franceschini (1993-1997) and Andrea Marchesi (2011; 2015), both of which are unmatched contributions to scholarship on Ferrara. A teacher whose university career at Ca'Foscari in Venice suffered permanent interruption with the onset of World War II, Franceschini scoured archives in Modena and Ferrara for documents relating to artists and artisans, which he then assembled into three tomes ${ }^{32}$. With exhaustive indices of artists, places and buildings, these massive tomes include materials that would otherwise take scholars years to unearthjust as it had Franceschini. Working without a computer and transcribing by hand in carefully organized notebooks (quaderni), Franceschini plowed through nearly two hundred years of materials, from contracts to payment registers to letters, to document the labor of artists on assignments from the most humble (replacement of fallen cornices) to the most privileged (Dosso Dossi's Polittico Costabili). Franceschini also included rental and purchase contracts, dowry statements, records of disputes and lawsuits, among many others, enormously expanding our knowledge of the ordinary lives of artisans and artists. Each entry includes a full citation, a brief summary of the nature of the document, followed by a full or partial transcription as appropriate. Something of the difficulty of sorting through often nearly illegible notarial calligraphy is visible in a few photographs of some of the most vexing examples included in each volume. The material Franceschini unearthed is stunning in its richness and will long be of incomparable value to historians.

Marchesi's volumes are equally significant, particularly for those interested in the built environment and architecture. Although they cover only the sixteenth century, in some respects they serve as useful fol-

\footnotetext{
${ }^{32}$ A fourth volume was completed in manuscript form before Franceschini's death in 2005 but publication has been halted because of squabbles among various interested parties.
} 
low-ups to Franceschini's research on fifteenth-century artisans. Many of the buildings documented here have either disappeared or undergone thoroughgoing transformation, rendering Marchesi's volumes particularly useful. Though confined to ducal properties, the documents also offer a compelling picture of ducal court life as well as the architectural and urban history of the duchy. Readers even learn about the funds disbursed by the Este to adorn the chambers of two Este nuns in the convent of Corpus Domini, Eleonora and Lucrezia (2015: 345-363). Marchesi also drew materials from notarial documents, financial registers, letters, published and unpublished chronicles. Where possible, he included images of the relevant properties. Like Franceschini's tomes, those of Marchesi include important additions, such as full indices, standards of transcription, charts of comparable weights and measures translated to today's standards, currencies, a glossary and a bibliography.

Today's scholar who browses through the chronicles and the compilations, perhaps in search of material on one individual, one event or one place or building, can only marvel at the dedication and exceptional talent of the various authors who conduct a labor of love often in adverse conditions and, until quite recently, without the aids upon which we today are so dependent (cameras, computers, internet resources) yet nonetheless managed to produce work of remarkable quality and significance. They have contributed in no small measure to a rebirth of interest in and scholarship on Ferrara at the peak of its glory as a center of Renaissance culture.

\section{References}

\section{Manuscripts}

Archivio di Stato di Modena. Modena. Casa e Stato, Genealogie, B. 60, Cronica della Casa d'Este.

Biblioteca Apostolica Vaticana. Roma. Fondo Chigi, I 4. Caleffini, Ugo, Croniche.

Biblioteca Comunale Ariostea. Ferrara. ms. cl. I, 470. Zambotti, Silva Cronicarum Bernardini Zambotti Juris Civilis Doctoris Ferrariensis sed incepta dum esset scolaris anno MCCCCLXXV.

Biblioteca Nazionale. Firenze. Fondo Magliabecchiano, XXV, 539. Caleffini, Ugo. Cronaca di Ferrara dalle origini al 1471. 
Biblioteca Universitaria Estense. Modena. Ms. it. 178, alpha F.5.18. Girolamo M. Ferrarini, Memoriale Estense.

British Library, London. Ms. 22324. Giulio Mosti and Girolamo Merenda. Annali di Ferrara.

\section{Bibliography}

Bellonci, Maria. 1939. Lucrezia Borgia. La sua vita e il suo tempo. Milan: Mondadori.

Bradford, Sarah. 2004. Lucrezia Borgia: Life, Love and Death in Renaissance Italy. London: Viking Penguin.

Broad, C. P. 1965. Tasso: A Study of the Poet and of his Contribution to English Literature. Cambridge: Cambridge University Press.

Caleffini, Ugo. 1938-40. Diario ferrarese (1471-1494). In Pardi, Giuseppe (ed.), 2 vol. Ferrara: Reale Deputazione di Storia Patria per l'Emilia e la Romagna, serie dei Monumenti, Tipografia Sociale.

Caleffini, Ugo. 2006. Croniche: 1471-1494. In Bacchi, Teresa \& Galli, Maria Giovanna (eds.), 2 vol. Ferrara: Deputazione Provinciale Ferrarese di Storia Patria.

Cappelli, A. 1867. Notizie di Ugo Caleffini notaro Ferrarese de secolo XV con la sua cronaca in rima di Casa d'Este. In Atti e Memorie della Deputazione Modenese di Storia Patria, s. I, II, 267-312.

Catalano, Michele. 1930-31. Vita di Ludovico Ariosto ricostruita su nuovo documenti, 2 vol. Geneva: Olschki.

Chiappini, Luciano. 1954. Indagini attorno a cronache e storie ferraresi del XV secolo. Rovigo: STER.

Ferrarini, Girolamo M. \& Griguolo, Primo (ed.). 2006. Memoriale Estense (1476-1489). Rovigo: Minelliana.

Folin, Marco. 2000. Le cronache a Ferrara e negli Stati estensi (secoli XVXVI). In Prosperi, Adriano (ed.) Storia di Ferrara. Il Rinascimento. Situazioni e personaggi, VI. Ferrara: Corbo.

Franceschini, Adriano. 1993-1997. Artisti a Ferrara in età umanistica e rinascimentale. Testimonianze archivistiche. 1341-1516, 3 vol. Ferrara: Corbo.

Ghirardo, Diane. 2014. Ludovico dalle Caselle di Gaiba nella Ferrara del Quattrocento. In AA. VV., Gaiba nella Grande Storia. Rovigo: Minelliana. 99-127.

Guerzoni, Guido. 2001. Le Corti Estensi e la Devoluzione di Ferrara del 1598. Modena: Archivio di Stato di Modena. 
Gullino, Giuseppe (ed.). 2011. L'Europa e la Serenissima. La Svolta del 1509 nel $V$ centenario della battaglia di Agnadello. Venezia: Istituto Veneto di Scienze, Lettere ed Arti.

Gunsberg, Maggie. 1998. The Epic Rhetoric of Tasso: Theory and Practice, Oxford: Oxford University Press.

Imbruglia, Girolamo. 2012. Muratori, Ludovico Antonio. In Dizionario Biografico degli Italiani, vol. 77. Roma: Istituto dell'Enciclopedia italiana. http://www.treccani.it/enciclopedia/ludovico-antonio-muratori_ (Dizionario-Biografico)/

Manni, Graziano. 2006. Belfiore. Lo studiolo intarsiato di Leonello d'Este. Modena: Artioli.

Marchesi, Andrea. 2011. Delizie d'Archivio. Regesti e documenti per la storia delle residenze estensi nella Ferrara del Cinquecento, tomo I, dimore suburbane ed extraurbane. Ferrara: Le Immagini.

Marchesi, Andrea. 2015. Delizie d'Archivio. Regesti e documenti per la storia delle residenze estensi nella Ferrara del Cinquecento, tomo II, dimore urbane. Ferrara: Le Immagini.

Masetti Zannini, Gian Ludovico. 2000. La capitale perduta: la devoluzione di Ferrara 1598 nelle carte vaticane. Ferrara: Corbo.

Muratori, Ludovico (ed.). 1738. Diario ferrarese di autori incerti dall'anno 1409 sino al 1502. In Rerum Italicarum Scriptores, Raccolta degli Storici dal cinquecento al millecinquecento, 1723-1751, tomo XXIV, vol. VII, Parte I. Milano: Tipografia Società Palatina in Regia Curia.

Muratori, Ludovico. 1717/1740. Delle antichità estensi ed italiane, 2 vol. Modena: Stamperia Ducale.

Pardi, Giuseppe (ed.). 1928-1933. Diario ferrarese dall'anno 1409 sino al 1502 di autori incerti. In Rerum Italicarum Scriptores, New revision, tomo XXIV, vol. VII, parte II. Bologna: Nicola Zanichelli.

Petrucci, Franca. 1973. Caleffini, Ugo. In Dizionario Biografico degli Italiani, XVI, vol 16. Roma: Istituto dell'Enciclopedia Italiana, 647-50.

Sambin De Norcen Page, Maria Teresa. 2013. Le ville di Leonello d'Este. Ferrara e le sue campagne agli albori dell'età moderna. Padua: Marsilio.

Sanuto, Marino. (1880). I Diarii di Marino Sanuto (MCCCCXCVI-MDXXXIII) dall'autografo Marciano ital. Cl. VII codd. CDXIX-CDLXXVII. Vol. IV. Visentini, F (ed.). Venezia: Deputazione veneta di storia patria.

Shephard, Tim. 2014. Echoing Helicon: Music, Art and Identity in the Este Studioli, 1440-1530. Oxford/London: Oxford University.

Tuohy, Thomas. 1996. Herculean Ferrara: Ercole d'Este, 1471-1505, and the Invention of a Ducal Capital. Cambridge: Cambridge University Press. 
Zambotti, Bernardino. 1934-37. Diario ferrarese dall'anno 1476 sino al 1504. In Pardi, Giuseppe (ed.), Rerum Italicarum Scriptores, new revision, tomo 24, tomo 7. Bologna: Nicola Zanichelli.

Zatti, Sergio. 2006. The Quest for Epic: From Ariosto to Tasso, ed. and trans. Dennis Looney. Toronto/London: University of Toronto Press.

Zerbinati, G. M. 1988. Memorie. In Monumenti della Deputazione provinciale Ferrarese di Storia Patria, XIII, 7-32.

Zerbinati, Giovanni Maria. 1989. Croniche di Ferrara quali comenzano del anno 1500 sino al 1527. Muzzarelli, Maria Giuseppina (ed.). Ferrara: Deputazione Provinciale Ferrarese di Storia Patria. 
